\title{
Pelagic Cnidaria and Ctenophora diversity patterns and trends in Macaronesia insular systems (NE Atlantic)
}

\author{
Sonia K. M. Gueroun ${ }^{1,2}$ - Jamileh Javidpour ${ }^{3} \cdot$ Carlos Andrade $^{2,4,5} \cdot$ Natacha Nogueira $^{2} \cdot$ Mafalda Freitas $^{1,4,6}$. \\ João Canning-Clode ${ }^{1,7}$
}

Received: 14 May 2020 / Revised: 16 January 2021 / Accepted: 15 February 2021 / Published online: 20 March 2021

(C) The Author(s) 2021

\begin{abstract}
Jellyfish are important components of the marine ecosystem and present a potential resource for different economic domains (e.g. medicine, food and biotechnology). We present an overview of the current state of jellyfish biodiversity in the Macaronesia region, which includes the archipelagos of the Azores, Madeira, the Canary Islands and Cape Verde, and examine possible biogeography patterns among its archipelagos. Based on a comprehensive literature survey, historical records, richness estimation and biogeographical distribution, our search included organisms belonging to Scyphozoa, Hydrozoa (strictly benthic species excluded) and Ctenophora. Our search detected 229 jellyfish species, with a dominance of holoplankton species, likely reflecting the insular and coastal morphology of the archipelagos. Differences in species richness, endemism and species affinities are found between the Azores, Madeira, Canary and Cape Verde island systems. Shared trend includes the dominance of holoplanktonic hydrozoans, while the second most speciose taxa (Scyphozoa and Ctenophore) vary between the archipelagos. While widespread distributed holoplankton predominate in the area, species with strict affinities suggests a pattern in the spatial distribution of jellyfish, dividing Macaronesia into two biogeographic units: (i) Azores-Madeira-Canary with temperate and subtropical and/or tropical species and (ii) Cape Verde with strictly subtropical and/or tropical species
\end{abstract}

Keywords Azores $\cdot$ Biodiversity $\cdot$ Canary Islands $\cdot$ Cape Verde $\cdot$ Jellyfish $\cdot$ Madeira

\section{Introduction}

Jellyfish are important components of the marine ecosystem, comprising a diverse group formed by pelagic cnidarians,

Communicated by S. Ohtsuka

Sonia K. M. Gueroun

sgueroun@mare-centre.pt

1 MARE - Marine and Environmental Sciences Centre, Agência Regional para o Desenvolvimento da Investigação Tecnologia e Inovação (ARDITI), Madeira, Portugal

2 Maricultura Centre of Calheta, Calheta, Madeira, Portugal

3 Department of Biology, University of Southern Denmark, Odense, Denmark

4 Madeira Oceanic Observatory (OOM), Funchal, Madeira, Portugal

5 Interdisciplinary Centre of Marine and Environmental Research (CIIMAR/CIMAR), University of Porto, Porto, Portugal

6 DRM Regional Directorate for the Sea, Madeira, Portugal

7 Smithsonian Environmental Research Center, Edgewater, MD, USA including Hydrozoa, Scyphozoa and Cubozoa, and ctenophores (Lucas and Dawson 2014). In recent decades, interest in jellyfish has increased as attested by the escalation of scientific literature and technical reports in the general media (Vandendriessche et al. 2016). This interest emanates from the global perception that jellyfish blooms have increased, with various consequences for human activities (e.g. fisheries, aquaculture, tourism and power plants) and ecosystems (Purcell et al. 2007). However, scientists have failed to reach a common consensus on whether jellyfish are increasing globally (Condon et al. 2012, 2013), as this issue has yet to be examined and seems to result from misinterpretations of several publications (Sanz-Martín et al. 2016).

Although jellyfish represent a food resource for several marine animals (Sweetman and Chapman 2015; Marques et al. 2016; Thiebot et al. 2017), it is their predation role that is often highlighted. They are both competitors and predators for fish larvae and zooplanktivorous fish as they feed on zooplankton and eat fish eggs and larvae (Purcell et al. 2015; Tilves et al. 2016). Moreover, the introduction of nonindigenous species (NIS), facilitated either by anthropogenic 
activities (e.g. ballast water and hull fouling on ships, artificial or natural canal construction or enlargement) or by natural spreading enhanced by global changes, has emphasized their impacts (Garcia and Durbin 1993).

Jellyfish exhibits various life strategies. Most of these gelatinous organisms display a bipartite life cycle, including polyps (benthic and sessile) and medusae (mostly planktonic and swimming). Some hydrozoans (Siphonophorae, Narcomedusae, Trachymedusae and Geryoniidae family in Limnomedusae), ctenophores and a few scyphozoans species like Pelagia noctiluca (Rottini Sandrini and Avian 1991) are strictly holoplanktonic. Pelagic and benthic stages are efficient predators constituting a significant link in bentho-pelagic coupling. The hydrozoans attribute of exhibiting different life strategies (benthic, meroplanktonic, holoplanktonic) have been used to assess possible pattern in different regions (Gibbons et al. 2010; Ronowicz et al. 2019). The presence of adequate substrates for hydroids/benthic settlement and seafloor morphology seems to play an important role in the distribution of species based on their life strategy. For instance, meroplanktonic hydrozoans tend to be progressively replaced by holoplanktonic species, as one moves away from the coast (Sabatés et al. 2010), while the low richness of benthic species in some areas in South Africa and Arctic might be related to the absence of suitable hard substrates (Gibbons et al. 2010; Ronowicz et al. 2019).

The Macaronesian region, located in the Northeast Atlantic Ocean, encompasses four oceanic archipelagos, comprising from north to south the Azores, Madeira (also including Selvagens and Porto Santo islands), the Canary Islands and Cape Verde. These archipelagos have developed sea-related activities including tourism and/or offshore fish farms, both of which are known to be affected by jellyfish including stung and fish farm mortality (Baxter et al. 2011; Ghermandi et al. 2015; Bosch-Belmar et al. 2016). These island systems share similar geographical features and geomorphological traits as they all have a volcanic origin, resulting in them becoming geologic hotspots for divers (Carracedo 2001). The four archipelagos, present in different latitude, display different geological age that influences the seafloor characteristics (Fig. 1) (Whittaker and Fernández-Palacios 2007). Hydrologically, three of the archipelagos (the Azores, Madeira and the Canary Islands) are interconnected via oceanic currents (Morton et al. 1998).

Recognition of the Macaronesia biogeography concept has raised some debate over the years. The first reference to Macaronesia goes back to Engler (1879), who recognized the Azores, Madeira and the Canary Islands as a single biogeographical unit, emphasized by endemic terrestrial flora such as Lauraceae plant species (Vanderpoorten et al. 2007). The inclusion of Cape Verde in Macaronesia only occurred several decades later (Dansereau 1961). Among the three archipelagos, Azores, Madeira and Canary Islands, sister areas tend to change depending on the taxa/phylum used for the biogeography study. For instance, based on the species composition of ichtyofauna (Lloris et al. 1991), Cirripedia (Quinteiro et al. 2015) and shallow subtidal macroalgae (Sangil et al. 2018), the Lusitanian Macaronesia has been divided into two biogeographic areas, one comprising Madeira and the Canary Islands and the other comprising only the Azores. One the other hand, Vanderpoorten et al. (2007) and later Tuya and Haroun (2009) featured Azores and Madeira as sister areas based on algae and pteridophyte diversity. Some studies have used a more global approach in biogeography concept analysis. Based on their biota, Spalding et al. (2007) divided the Macaronesia region into two biogeographic units, with the Azores, Madeira and the Canary Islands regrouped as a single ecoregion within the Lusitanian province in the temperate Northern Atlantic Realm, while Cape Verde was considered as a separate ecoregion within the West African Transition province in the Tropical Atlantic Realm. A recent multiple-marine taxon biogeographical approach excluded Cape Verde from the Macaronesia biogeographic unit (Freitas et al. 2019). This approach redefined the Lusitanian biogeographical province as a new ecoregion (Webbnesia), comprising Madeira, Selvagens and the Canary Islands, while the Azores were relegated to an ecoregion, along with two other ecoregions (the South European Atlantic Shelf and the Saharan Upwelling).

Existing knowledge of Macaronesia jellyfish diversity as well as its role in human activities, ocean products (e.g. cosmetic based on jellyfish collagen, jellyfish as food or aqua feed) or as a potential environmental indicator appears to be inchoate. To date, little is known about jellyfish diversity in Macaronesian waters. An additional area of interest lies in the possible influence of the insular nature on the community (e.g. endemism). In this context and in order to expand our current understanding of the scale and diversity of jellyfish on insular systems, we examined jellyfish diversity patterns in the Macaronesia region. Based on literature research and on estimations, we investigated the current state of jellyfish biodiversity in the whole of Macaronesia by examining possible patterns and biogeographical distinctions between the archipelagos. Specifically, we tested two hypotheses: (1) due to its insular and geological nature, Macaronesia favours holoplanktonic species over meroplanktonic species; (2) due to the wide geographical distribution of holoplanktonic jellyfish (mainly Hydrozoa), we assume that Macaronesia constitutes a single biogeographic region.

\section{Material and methods}

\section{Data collection}

We conducted a literature search focused on jellyfish diversity across the whole of Macaronesia (Fig. 1). The term "jellyfish" 
Fig. 1 The Macaronesia region, comprising the four archipelagos of the Azores, Madeira, the Canary Islands and Cape Verde. Arrows illustrate the circulation pattern of the main surface currents in the North and Central Atlantic Ocean. GS-Gulf Stream; NAC-North Atlantic Current; AC-Azores Current; SWECSouthwest European Current; MADC-Madeira Current; CANC-Canary Current; NECNorth Equatorial Current; NECC-North Equatorial Counter Current; MC-Mauritania Current; GC-Guinea Current. Dashed line: Cape Verde Frontal Zone

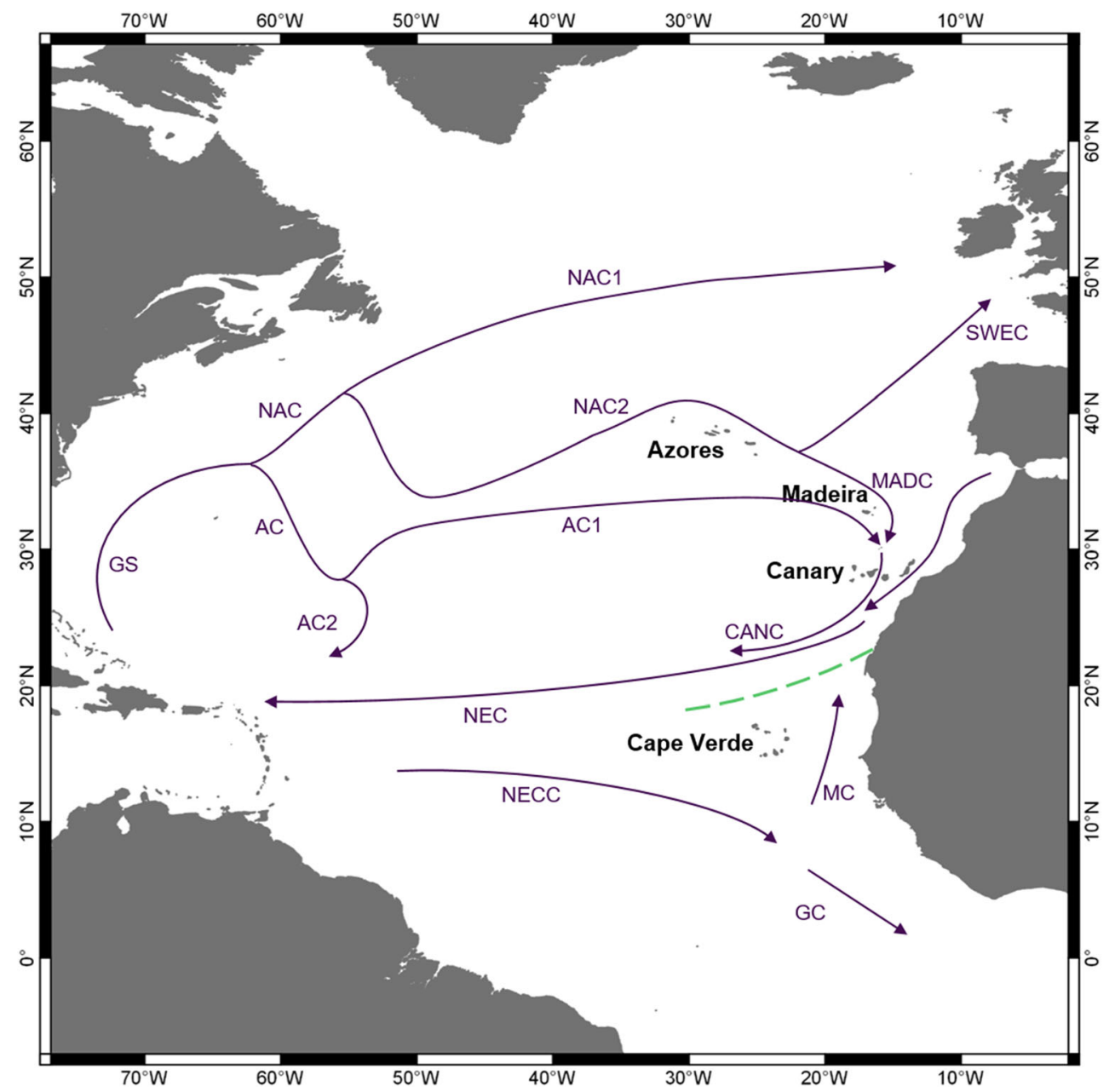

used for this analysis refers to Hydrozoa, Scyphozoa and Cubozoa Class and Ctenophora phylum. The datasets were based on the compilation of all records existing in the scientific literature and grey literature such as books, book chapters, cruise reports and theses (both master's and doctoral). The search mainly involved exploring the Google Scholar database for the following relevant keywords: "Hydrozoa", "Scyphozoa", "Cubozoa", "Medusa", "Ctenophore", "jellyfish" and "hydroids" associated (AND) with the four archipelagos names "Azores", "Madeira", "Canary Islands" and "Cape Verde" in English, Portuguese and Spanish languages. Only hydrozoan species with pelagic phase (meroplankton and holoplankton) were considered based on Bouillon et al. (2006) review. Exclusively benthic species (medusa-lacking species) were excluded. Species taxonomic validity status, synonyms and names were checked on World Register of Marine Species database (WoRMS) (Horton et al. 2020). Species with uncertainty and doubtful status were removed. The classification adopted was the one proposed by Daly et al. (2007) for the Cnidaria phylum and from the WoRMS (in 2019) for Ctenophora phylum.

\section{Data analysis}

A non-parametric incidence-based estimator (presenceabsence) was used to assess total estimated jellyfish species richness at the region (Macaronesia) and archipelago levels (Azores, Madeira, Canary Islands, Cape Verde). In this context, the second-order Jackknife estimator (Jack2) (Smith and van Belle 1984) was selected given its prime performance with different levels of replication in marine benthic communities (Canning-Clode et al. 2008). The second-order Jackknife is based on the species occurring in only one sample as well as in the number that occur in exactly two samples. The sample unit used corresponds to the sampling campaigns.

To detect a potential pattern in jellyfish distribution, several analyses were performed: first, similarity between jellyfish diversity among the four archipelagos was examined using the Jaccard similarity coefficient, which takes the following form:

$C_{\mathrm{j}}=j /(a+b-j)$,

where $j$ is the number of family/genus/species found in two archipelagos, $a$ represents the number of species in 
Table 1 Comparison of oceanographic, geological and abiotic features of Macaronesian islands systems abiotic and geological characteristic (Ávila et al. 2018)

\begin{tabular}{lrrrrr}
\hline Archipelagos & No. main islands & Average latitude & Mean annual SST $\left({ }^{\circ} \mathrm{C}\right)$ & Age (Ma) & $\begin{array}{r}\text { Isolation (km) } \\
\text { Littoral area } \\
(0-200 \mathrm{~m}) \mathrm{km}^{2}\end{array}$ \\
\hline Azores & 9 & $38.18 \mathrm{~N}$ & 17.6 & 6 & 4846 \\
Madeira & 5 & $32.45 \mathrm{~N}$ & 20.15 & 18.8 & 285 \\
Canary & 7 & $28.31 \mathrm{~N}$ & 21.45 & 25 & 98 \\
Cape Verde & 10 & $16.00 \mathrm{~N}$ & 24.5 & 15.8 & 570 \\
\hline
\end{tabular}

archipelago A and $b$ represents the number of species in archipelago B.

A correspondence analysis (CA) was performed to assess a potential biogeography pattern in the island systems based on species climate affinity and life cycle. The spatial distributions of hydrozoans and ctenophores were extracted from Bouillon et al. (2004) and from WoRMS. For the latter, only the distributions labelled "Checked: verified by a taxonomic editor" and "Trusted: edited by a thematic editor" were retained (page generated on 19 June 2019). The distribution of Scyphozoa was extracted from the World Atlas of Jellyfish (Jarms and Morandini 2019). The species were then divided into five groups based on their geographical distribution: (1) $T$ : species strictly distributed in temperate areas; (2) $P T$ : species distributed in polar or in polar and temperate areas; (3) TTrop: species widely distributed in temperate and subtropical and/or tropical areas; (4) Trop: species strictly distributed in subtropical and/or tropical areas; (5) Cos: cosmopolite species distributed from polar to tropical regions. Due to temperature vertical profile, deep-sea species are often associated with cool temperature. Therefore, in order to

Table 2 Diversity of jellyfish (hydrozoans, scyphozoans and ctenophores) in Macaronesia islands systems

\begin{tabular}{|c|c|c|c|c|c|}
\hline & Macaronesia & Azores & Madeira & Canary & Cape Verde \\
\hline \multicolumn{6}{|l|}{ No. of species } \\
\hline All & 229 & 114 & 38 & 102 & 88 \\
\hline Hydrozoa & 191 & 101 & 36 & 77 & 71 \\
\hline Scyphozoa & 20 & 10 & 2 & 10 & 11 \\
\hline Ctenophora & 18 & 3 & 0 & 15 & 6 \\
\hline \multicolumn{6}{|l|}{ No. of genera } \\
\hline All & 144 & 83 & 28 & 78 & 65 \\
\hline Hydrozoa & 117 & 74 & 56 & 59 & 52 \\
\hline Scyphozoa & 14 & 7 & 2 & 7 & 7 \\
\hline Ctenophora & 13 & 2 & 0 & 11 & 6 \\
\hline Range of species per genus & $1-10$ & $1-5$ & $1-6$ & $1-4$ & $1-5$ \\
\hline Max. representative & Clytia & Clytia, Obelia & Clytia & Nausithoe & Clytia, Hydractinia \\
\hline \multicolumn{6}{|l|}{ No. of family } \\
\hline All & 74 & 44 & 22 & 52 & 48 \\
\hline Hydrozoa & 53 & 36 & 20 & 36 & 36 \\
\hline Scyphozoa & 12 & 6 & 2 & 7 & 7 \\
\hline Ctenophora & 9 & 2 & 0 & 9 & 5 \\
\hline Range of genera per family & $1-9$ & $1-7$ & $1-4$ & $1-8$ & $1-6$ \\
\hline Max. representative & Rhopalonematidae & Prayidae & Diphyidae & Rhopalonematidae & Rhopalonematidae \\
\hline Range of species per family & $1-26$ & $1-10$ & $1-9$ & $1-9$ & $1-8$ \\
\hline Max. representative & Campanulariidae & Campanulariidae, Prayidae & Campanulariidae & Rhopalonematidae & Campanulariidae \\
\hline \multicolumn{6}{|l|}{ Life strategy } \\
\hline No. of meroplankton (\%) & $112(49 \%)$ & $47(41 \%)$ & $25(66 \%)$ & $38(37 \%)$ & $51(58 \%)$ \\
\hline No. of holoplankton (\%) & $117(51 \%)$ & $67(59 \%)$ & $13(34 \%)$ & $64(63 \%)$ & $37(42 \%)$ \\
\hline
\end{tabular}


identify potential pattern based on habitat temperature, only epipelagic species were used for this analysis. Vertical profile of each species was identified through literature research. Species showing vertical migration between epipelagic and mesopelagic zones were also considered.

Finally, genus with un-identified species (genus $s p$ or genus $s p p$ ) was removed from the analysis, unless the genus was only recorded in one of the archipelagos. CA and Jaccard similarity were performed using MVSP software. Jackknife estimator coefficient was performed using $\mathrm{R}$ version 3.3.3 (R Core Team 2017) and SpadeR package (Chao et al. 2016) (Table 1).

\section{Results}

We compiled a total of 229 recorded species belonging to the Hydrozoa, Scyphozoa and Ctenophora from references published since 1879 (until 2019) (Supplement 1, 2). No cubozoan has been recorded in any of the four-macaronesian island systems. Azores is the most diverse archipelagos with 114 species, followed by Canaries (102), Cape Verde (88) and Madeira (38) (Table 2).

A total of 191 species of Hydrozoa belonging to 117 genera, 53 families and 6 orders were recorded in the Macaronesia. At highest taxonomic level, Siphonophorae is the most speciose order with 56 species in 35 genera. The others speciose orders are Anthoathecata with 53 species in 35 genus; Leptothecata with 45 species in 24 genera; Trachymedusae with 20 species in 14 genera; and Narcomedusae with 18 species in eight genera. The average number of species per family is 3.6, with Campanulariidae as the most speciose family (16 species; $8 \%$ of the Hydrozoa), followed by Rhopalonematidae (14 species; $7 \%$ of Hydrozoa) and Diphydae and Prayidae (11 species, respectively; $6 \%$ of the Hydrozoa, respectively). The most speciose genus is Clytia with 10 species (5\% of the Hydrozoa, $4 \%$ of all the records).

A total of 20 species of Scyphozoa belong to 14 genera, 12 families and 3 orders. At high taxonomic level, the Coronatae is the most diverse order with 12 species in seven genus (57\% of the Scyphozoa). The other orders are Semaeostomeae with four species in four genera (20\% of the Scyphozoa; Aurelia aurita doubtful removed) and the Rhizostomeae with three species in three genera (14\% of the Scyphozoa). The average number of species per family is 1.8 , with Nausithoidae family as the most speciose with four species. The other speciose families are the Atollidae with three species in one genus (14\% of the Scyphozoa) and Periphyllidae with two species in two genera (10\% of the Scyphozoa).

A total of 18 species Ctenophora recorded in Macaronesia belong to 13 genera, 9 families and 4 order. At high taxonomic level, the Cydippida order is the most diverse order with eight species in five genera ( $44 \%$ of the ctenophores). The other speciose order is the Lobata with five species in five genera ( $28 \%$ of the ctenophores). The average number of species per family is two, with the Pleurobrachiidae as the most species family with six species (33\% of ctenophores).

The species distribution between the orders within each main taxa (Hydrozoa, Scyphozoa and Ctenophora) varies between the macaronesian archipelagos: in Hydrozoa, Siphonophorae is dominant in Azores (35\%) and Canary $(32 \%)$, Leptothecata predominates in Madeira (36\%), and Anthoathecata and Leptothecata dominate in equal proportion in Cape Verde (30\%) (Fig. 2a). For the Scyphozoa, Coronatae predominates the scyphozoan in Cape Verde $(73 \%)$, the Canary (70\%) and Azores (55\%), while Semaeostomeae is the only order recorded in Madeira (Fig. 2b). Among
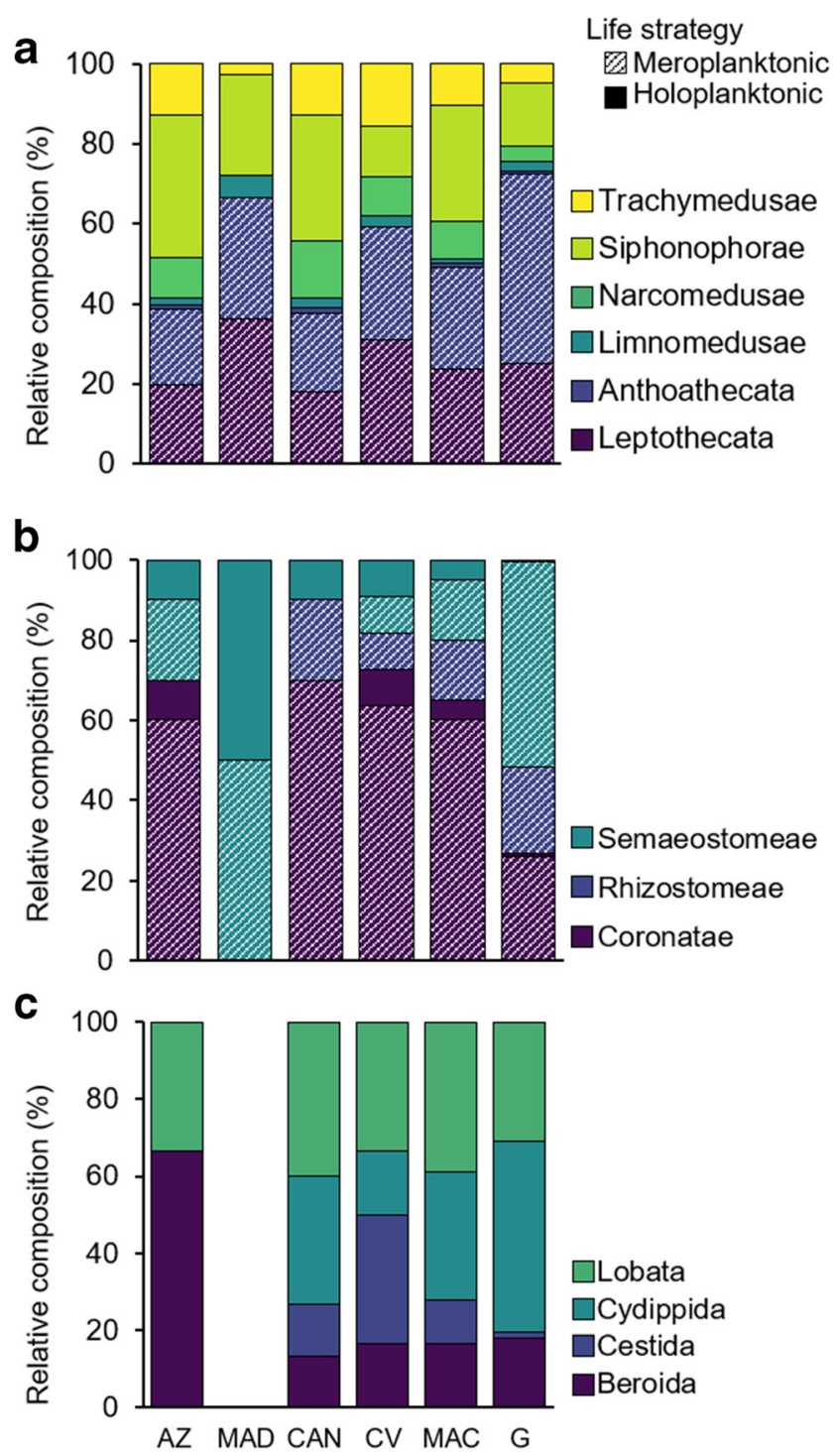

Fig. 2 Macaronesian relative composition of the jellyfish order in a pelagic hydrozoans, b scyphozoan, c ctenophores. Abbreviations as follows: MAC: Macaronesia; AZ: Azores; MAD: Madeira; CAN: Canary Islands; CV: Cape Verde; G: global data (extracted from Bouillon et al. 2006; Jarms and Morandini 2019) 
ctenophores, dominant orders are represented by Beroida in Azores (67\%), Lobata in Canary (40\%) and by Lobata and Cestida in equal proportion in Cape Verde (33\%). No pelagic ctenophore has been recorded in Madeira (Fig. 2c) while the highest diversity has been recorded in Canary (14 species).

Several families $(91 \%)$ are represented by a single species: $23(49 \%)$ in Azores, 16 (73\%) in Madeira, 34 (64\%) in Canary and 27 (57\%) in Cape Verde. The most speciose Hydrozoa families in each archipelago correspond to the general Macaronesian trend but with variation between the areas: Campanulariidae and Prayidae in Azores (10 species, respectively), Campanulariidae in Madeira (nine species) and in Cape Verde (eight species) and Rhopalonematidae in Canary (nine species) (Fig. 3a). In Scyphozoan (Fig. 3b), the most speciose families are Nausithoidae ( 5 species) and Atollidae ( 3 species). This trend is observed in all the archipelagos except in Madeira where only one species for each of the Ulmaridae and Pelagiidae has been recorded. Macaronesia ctenophore diversity is mainly represented by the Pleurobrachiidae family with six species (Fig. 3c). The general ctenophore trend in the Macaronesia is driven by the species recorded in the Canary Islands, as few species are recorded in the others island systems. Clytia and Obelia are the most speciose genus in Azores (five species), Clytia in Madeira

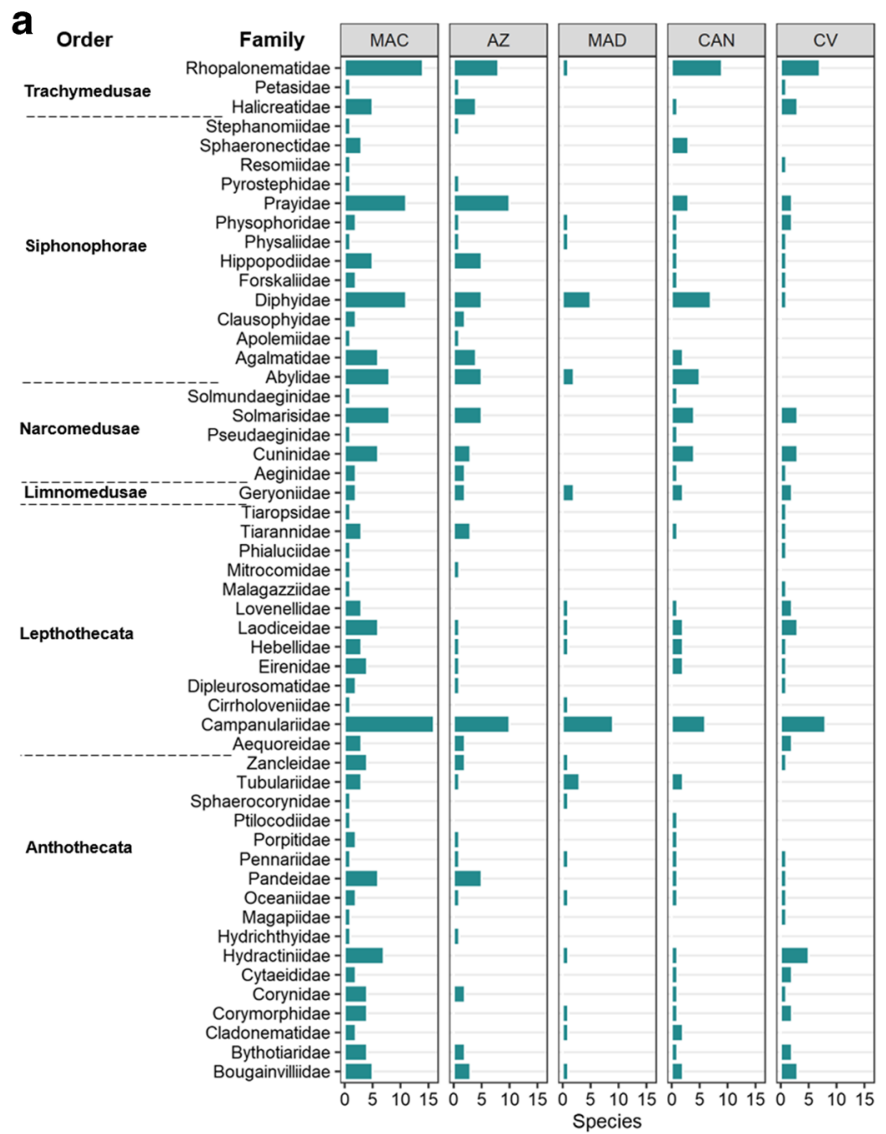

(seven species), and Clytia and Hydractinia in Cape Verde (five species, respectively). While the most speciose genus of these archipelagos belong to Hydrozoa, the most species genus in Canary is represented by the deep-water Nausithoe scyphozoans (four species).

Only 12 families (16\%; Rhopalonematidae, Physophoridae, Diphyidae, Cheloniidae, Laodiceidae, Heneliidae, Campanulariidae, Pennariidae, Oceaniidae, Bougainviliidae, Pelagiidae), ten genera (7\%, Liriope, Pantachogon, Pennaria, Clytia, Obelia, Physalia, Physophora, Chelophyes, Pelagia) and nine species (4\%, Liriope tetraphylla, Pantachogon haeckeli, Rhopalonema velatum, Pennaria disticha, Obelia bidentate, Obelia dichotoma, Physalia physalis, Physophora hydrostatica, Pelagia noctiluca) are common between the four archipelagos (Fig. 4a). Within the island systems, the Jaccard similarity index for these taxonomic levels showed the same trend (Fig. 4): the lowest values are recorded between Madeira and Cape Verde, with 0.24 for family (16 shared families), 0.20 for genus ( 15 shared genus) and 0.14 for species (15 shared species); conversely, the furthest island systems, Azores and Cape Verde, exhibited the highest values, with 0.35 for family ( 31 shared families), 0.33 for genus ( 26 shared genera) and 0.21 for species (33 shared species).

b

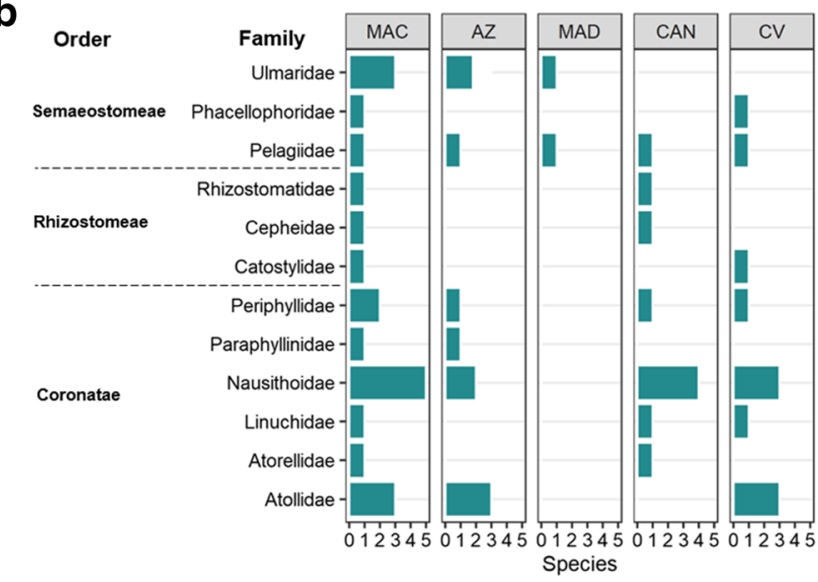

C

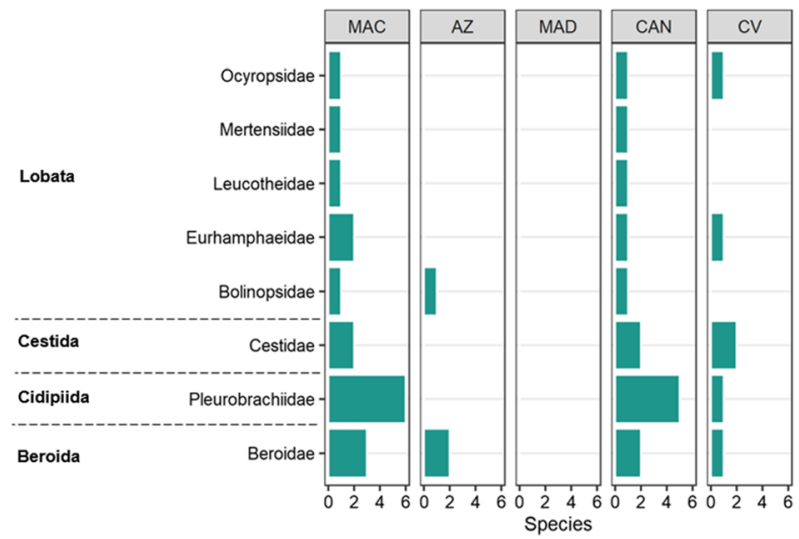

Fig. 3 Configuration of a hydrozoans; b scyphozoans; and $\mathbf{c}$ ctenophores diversity by families across the four archipelagos of Macaronesia. Abbreviations as follows: MAC: Macaronesia; AZ: Azores; MAD: Madeira; CAN: Canary Islands; CV: Cape Verde 

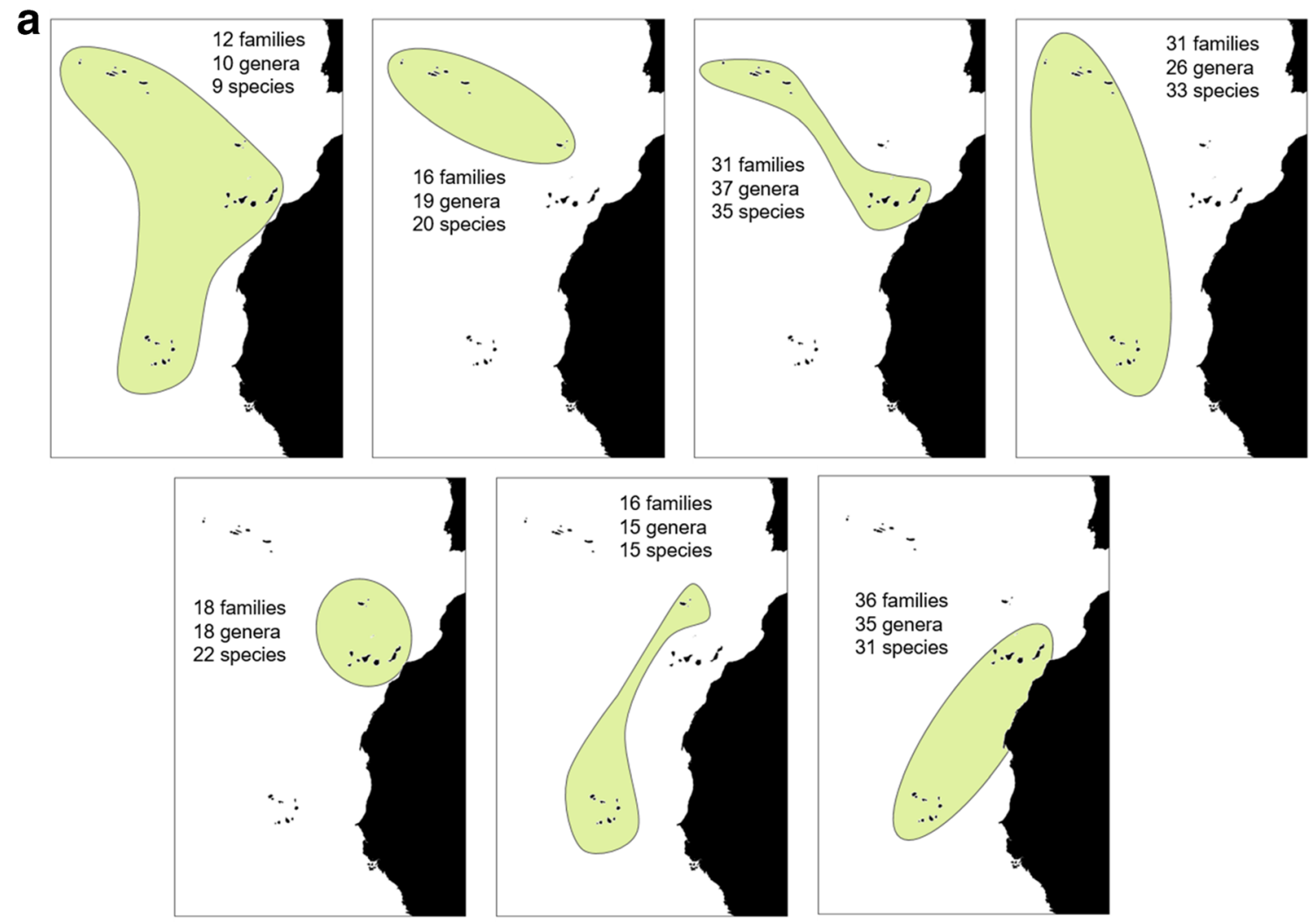

b
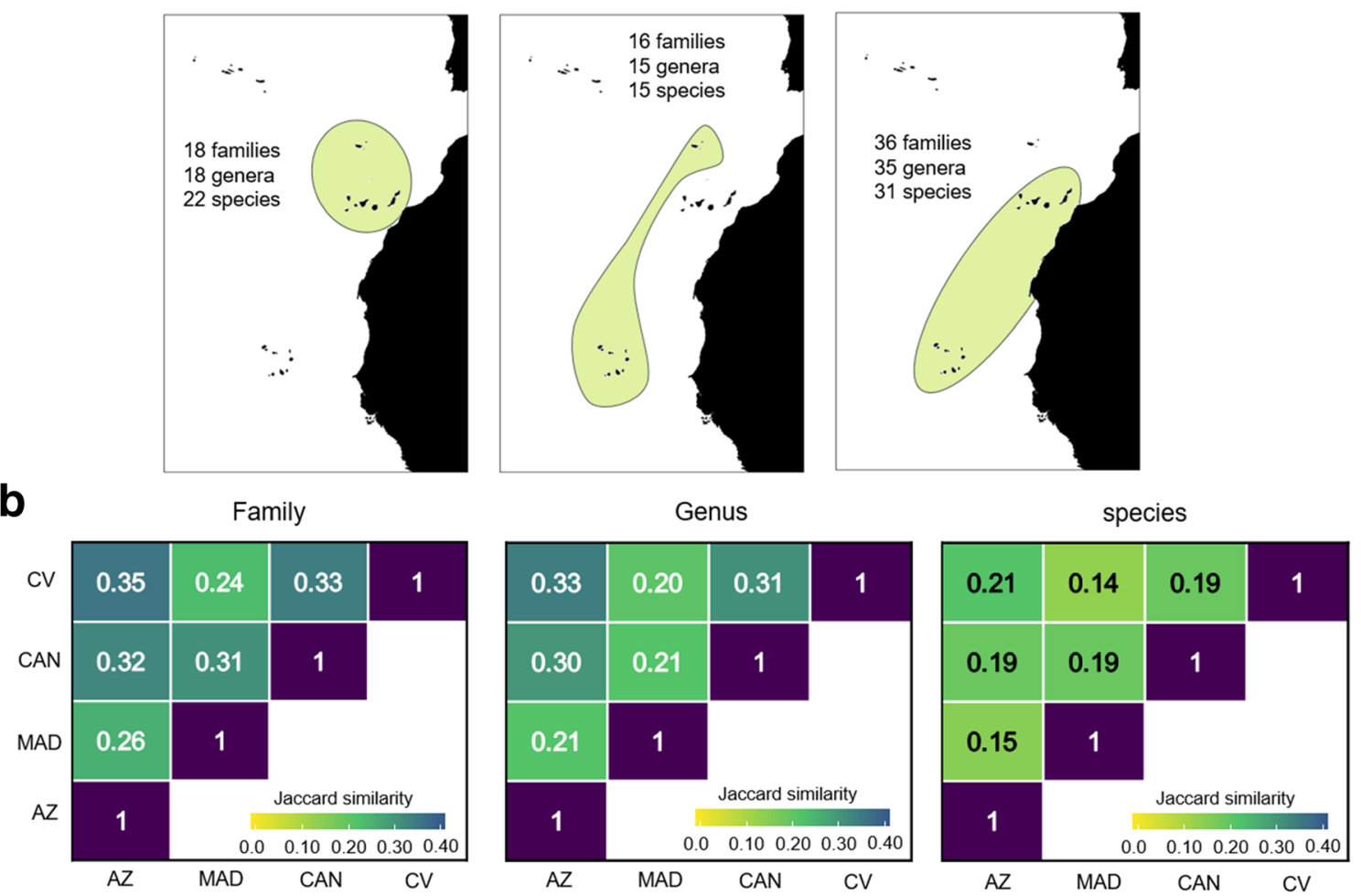

Fig. 4 a Shared families/genus/species and b correspondent Jaccard similarity index between the Macaronesian archipelagos. AZ: Azores; MAD: Madeira; CAN: The Canary Islands; CV: Cape Verde; H: Hydrozoa; S: Scyphozoa; C: Ctenophora

The shared species between the archipelagos are mainly represented by three orders namely Leptothecata, Siphonophorae and Trachymedusae. Some similarities and differences are remarkable (Fig. 5). Leptothecata is the main shared order for half of the cases: Madeira-Azores (37\%), Madeira-Cape Verde (47\%) and Canary-Cape Verde (19\%), where Obelia and Clytia are the main speciose genus. Canary Islands mainly shared siphonophores with Madeira (36\%) and Azores (26\%). Finally, mostly of common species (20\%) between Azores and Cape Verde belong to Trachymedusae order. All over, most of the species shared between the archipelagos, representing $55 \%$ and $75 \%$ of the shared species. Meroplankton dominated the common species only between Azores and Madeira (53\%) and between Madeira and Cape Verde (60\%).
In Macaronesia, 51\% (117 species) are holoplanktonic, mainly Hydrozoa (83\%): with 55 Siphonophorae (47\%), 20 Trachymedusae (17\%) and 18 Narcomedusae (15\%). Based on life strategy, Macaronesia jellyfish contrasts with the world global pattern of meroplankton dominance (71\%) (Fig. 2). At island systems level, some remarkable similarities as well as differences appear. Holoplankton taxa predominate in Canary (63\%) and Azores (59\%), mostly represented by siphonophores (54\% and $38 \%$, respectively). Conversely, meroplankton are more speciose in Madeira (66\%) and Cape Verde (58\%), both dominated by Leptothecata $(34 \%$ and $25 \%$, respectively).

The zoogeographical affinity of Macaronesian epipelagic cnidarians and ctenophores shows the dominance of widespread distributed species occurring in temperate- 


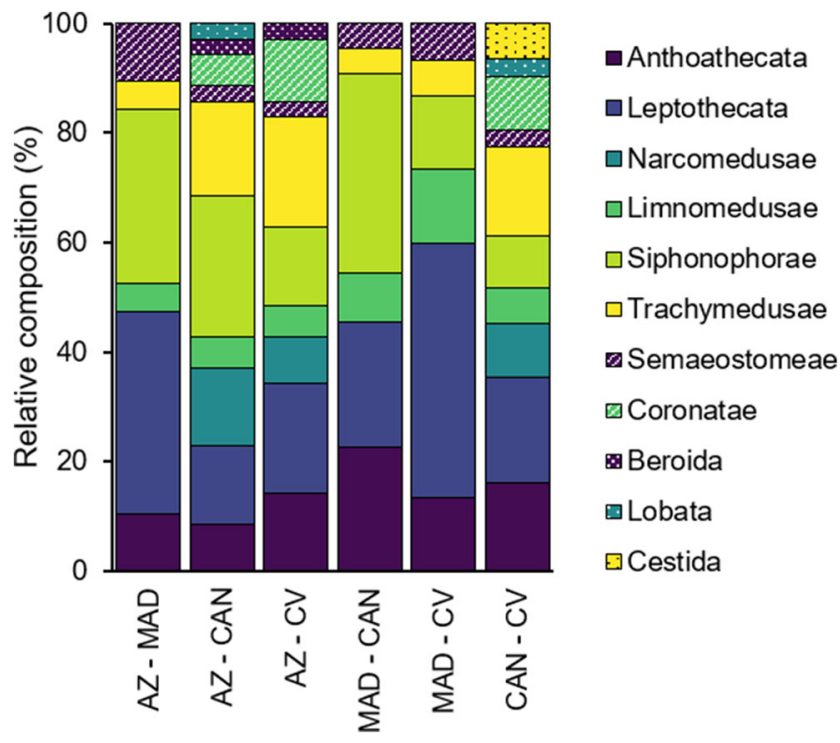

Fig. 5 Relative composition of the orders of the species common between two archipelagos. AZ: Azores; MAD: Madeira; CAN: The Canary Islands; CV: Cape Verde

subtropical-tropical (52\%) and in strictly temperate (35\%) regions. Although this general trend is common between Macaronesian island systems, Cape Verde stands out from the three other archipelagos (Fig. 6a) where a non-negligible proportion species $(16 \%)$ shows a strict distribution in subtropical and/or tropical regions. All these strictly subtropicaltropical species are meroplanktonic. While correspondence analysis showed an association between Azores and Canary islands with polar-temperate species, this trend is limited as this affinity represents only $2 \%$ and $18 \%$ of the species, respectively. A pattern also appears in the shared species between the archipelagos (Fig. 6b). Common holoplanktonic are widespread distributed species with temperate and subtropical/tropical affinity. One the other hand, the distribution of meroplankton is more dominated by temperate affinity species.

Endemism is exclusively represented by meroplanktonic hydrozoans (Table 3), with 8 species (2.8\% of Hydrozoa). Five are recorded in Cape Verde (7\%), two in Azores (2\%) and one in Canary (1.3\%). To date, there are no endemic pelagic cnidarians and/or ctenophores known from Madeira, neither endemic scyphozoan, ctenophores, family nor genus from Macaronesia.

In the studied area, a great majority of the species have been recorded as singletons, representing $58 \%$ of the total records. Therefore, Macaronesia pelagic cnidarians and ctenophore seem to be underestimated: the Jack2 index estimated a true jellyfish richness of 457 species, leading to an underestimation of $51 \%$ in terms of Macaronesia's jellyfish diversity (Fig. 7). Among the archipelagos, the Jack2 index varies from $53 \%$ (219 species) in the Azores to $43 \%$ (88 species) in Madeira. Looking at the different taxa, the inventory
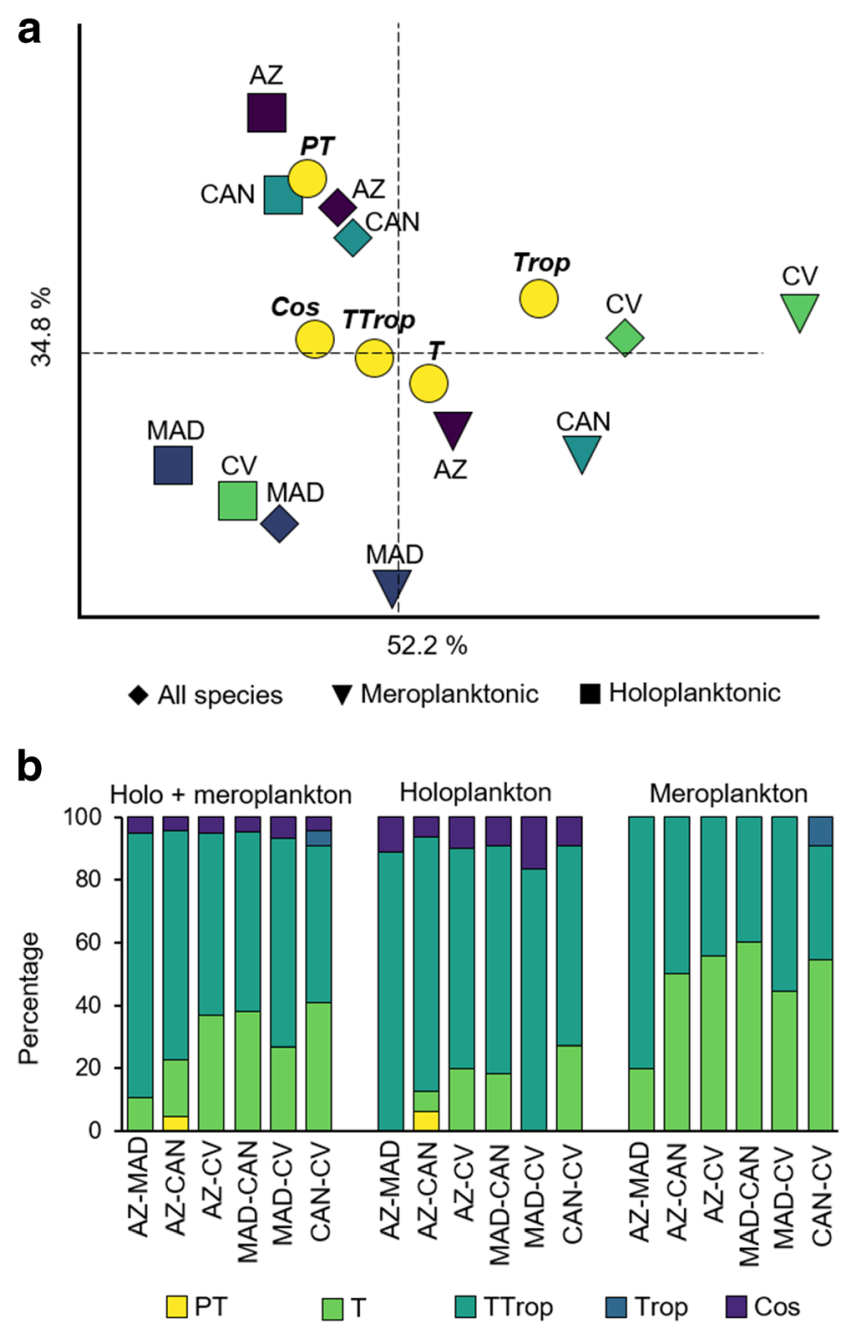

Fig. 6 Correspondence analysis scatterplot based on the life cycle and the distribution of a jellyfish recorded and $\mathbf{b}$ common in the four Macaronesian islands systems. AZ: Azores; MAD: Madeira; CAN: The Canary Islands; CV: Cape Verde: $T$ : temperate; $P T$ : polar or polar and temperate; TTrop: temperate and subtropical and/or tropical; Trop: subtropical and/or tropical; Cos: cosmopolite

completeness estimations were the highest for Ctenophora (68\%), followed by Scyphozoa (61\%) and Hydrozoa (51\%).

\section{Discussion}

Among the three classes defining pelagic cnidarians, no Cubozoa species have been detected in any of the four archipelagos composing Macaronesia. Nevertheless, several cubozoan species have been recorded on both sides of the Atlantic Ocean and its adjacent seas (Kramp 1955, 1961; Morandini 2003), and in some oceanic islands such as Bermuda (Bigelow 1938) and Saint Helena (Haeckel 1880). Little is known about cubozoan ecology as these invertebrates are regarded as rare jellyfish, difficult to detect and mostly abundant in shallow waters (Kingsford and Mooney 2014). 
Table 3 Species richness and endemism in different marine taxa in Macaronesia islands systems (after Freitas et al. 2019)

\begin{tabular}{|c|c|c|c|c|c|c|c|c|}
\hline Taxa & & $\mathrm{AZ}$ & MAD & CAN & $\mathrm{CV}$ & MAC & Common species* & Source \\
\hline \multirow[t]{3}{*}{ Hydrozoans } & No. of species & 101 & 36 & 77 & 71 & 191 & $4.7 \%$ & Present study \\
\hline & No. of endemism & 2 & 0 & 1 & 5 & 8 & - & \\
\hline & Endemism (\%) & 2.0 & 0.0 & 1.3 & 7.0 & 2.8 & - & \\
\hline \multirow[t]{3}{*}{ Scyphozoans } & No. of species & 10 & 2 & 10 & 11 & 20 & $5.0 \%$ & \\
\hline & No. of endemism & 0 & 0 & 0 & 0 & 0 & - & \\
\hline & Endemism (\%) & 0.0 & 0.0 & 0.0 & 0.0 & 0.0 & - & \\
\hline \multirow[t]{3}{*}{ Ctenophores } & No. of species & 3 & 0 & 15 & 6 & 18 & $0.0 \%$ & \\
\hline & No. of endemism & 0 & 0 & 0 & 0 & 0 & - & \\
\hline & Endemism (\%) & 0.0 & 0.0 & 0.0 & 0.0 & 0.0 & - & \\
\hline \multirow[t]{3}{*}{ Coastal fishes } & No. of species & 165 & 208 & 299 & 303 & 465 & $0.1 \%$ & Freitas et al. (2019) \\
\hline & No. of endemism & 1 & 0 & 2 & 22 & 25 & - & \\
\hline & Endemism (\%) & 0.6 & 0.0 & 0.7 & 7.3 & 5.4 & - & \\
\hline \multirow[t]{3}{*}{ Echinoderms } & No. of species & 64 & 69 & 85 & 76 & 151 & $5.9 \%$ & \\
\hline & No. of endemism & 0 & 0 & 0 & 1 & 1 & - & \\
\hline & Endemism (\%) & 0.0 & 0.0 & 0.0 & 1.3 & 0.7 & - & \\
\hline \multirow[t]{3}{*}{ Gastropods } & No. of species & 280 & 397 & 811 & 608 & 1,312 & $3.4 \%$ & \\
\hline & No. of endemism & 37 & 14 & 96 & 268 & 418 & - & \\
\hline & Endemism (\%) & 13.2 & 3.5 & 11.8 & 44.1 & 31.9 & - & \\
\hline \multirow[t]{3}{*}{ Brachyurans } & No. of species & 62 & 75 & 120 & 117 & 117 & $17.5 \%$ & \\
\hline & No. of endemism & 0 & 0 & 0 & 10 & 10 & - & \\
\hline & Endemism (\%) & 0.0 & 0.0 & 0.0 & 8.5 & 5.6 & - & \\
\hline \multirow[t]{3}{*}{ Polychaetes } & No. of species & 169 & 386 & 465 & 213 & 683 & $2.6(\%)$ & \\
\hline & No. of endemism & 1 & 10 & 10 & 9 & 30 & - & \\
\hline & Endemism (\%) & 0.6 & 3.3 & 2.2 & 4.2 & 4.4 & - & \\
\hline \multirow[t]{3}{*}{ Macroalgae } & No. of species & 405 & 396 & 689 & 333 & 949 & $10.4(\%)$ & \\
\hline & No. of endemism & 0 & 1 & 1 & 0 & 2 & - & \\
\hline & Endemism (\%) & 0.0 & 0.3 & 0.1 & 0.0 & 0.2 & - & \\
\hline
\end{tabular}

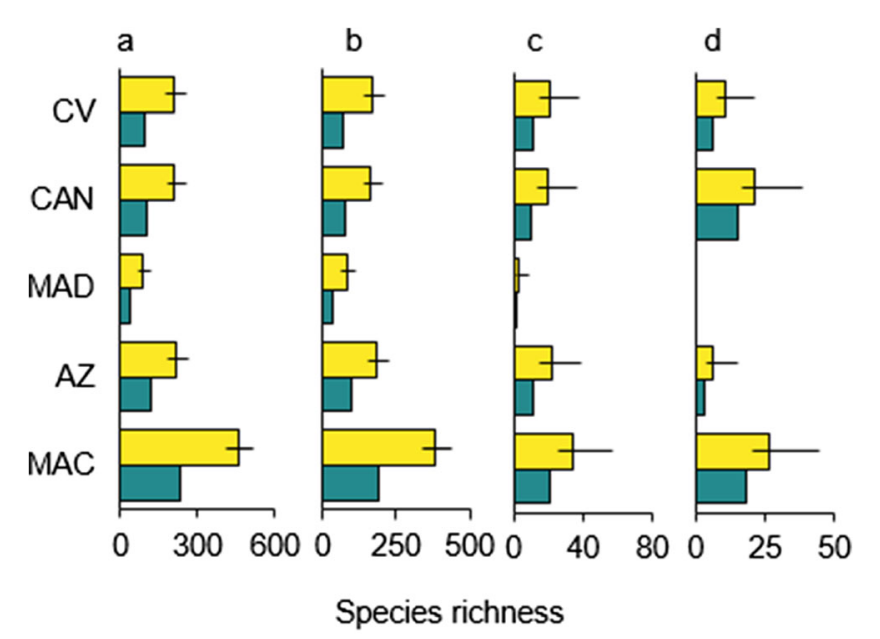

\section{Recorded \\ Estimated}

Fig. 7 Richness estimation of a jellyfish; b hydrozoans; $\mathbf{c}$ scyphozoans; and $\mathbf{d}$ ctenophores in the Macaronesian archipelagos based on Jack2. AZ: Azores; MAD: Madeira; CAN: Canary Islands; CV: Cape Verde
The absence of cubozoan records in Macaronesia is still unclear, might be relating to relative low sampling efforts across Macaronesia or due to the archipelagos' seafloor morphology characterized by the restricted shelves and steep slopes, although a number of other explanations could also be proposed.

The present study shows the dominance of hydrozoan with holoplanktonic life history strategy in Macaronesia. This pattern deviates from the global data (exclusive benthic not considered) and from equivalent datasets in other regions (South Africa (Gibbons et al. 2010) and Mediterranean sea (Bouillon et al. 2004)) where meroplankton species predominates. A comparison with another islands system, New Zealand (Schuchert 1996; Vervoort and Watson 2003; Cairns et al. 2009), where 59\% of pelagic hydrozoan present a bi-partite life cycle, highlights this peculiar pattern in Macaronesian hydrozoan diversity. This difference between New Zealand and Macaronesian island systems might be related to the geological features: New Zealand age (85 Ma) and geological 
origin (derived from Zealandia, part of the gondwanan supercontinent), extended coastline and continental shelf (up to $1000 \mathrm{~km}$ ) (Wallis and Trewick 2009). Moreover, Macaronesia is composed of volcanic oceanic islands that were never connected to a continental landmass with restricted shelf area and steep slopes near the coastline. All these morphologic and geologic features might explain the lower diversity of meroplanktonic hydrozoans. The influence of Macaronesian seafloor morphology (i.e. limited shelf, steep slopes) seems also to be expressed in scyphozoan diversity, mainly by Coronatae. This trend contrasts with the worldwide scyphozoan richness where Semaeostomeae is the most speciose order (115 valid species) while Coronatae is the least speciose (59 valid species) (Jarms and Morandini 2019). In Scyphozoa, Rhizostomeae are considered to be shallow or epibenthic medusae while Coronatae and Semaeostomeae are pelagic, the latter being neritic or oceanic (Matsumoto et al. 2003). Traditionally, Coronatae jellyfish are considered as mesopelagic to bathypelagic medusa (Arai 1997). However, only Atollidae, Periphyllidae and Paraphyllinidae families, represented in Macaronesia by five species, are exclusively deep-water species; the other species display a midto deep water distribution (Jarms et al. 2002).

Marine biodiversity patterns and zoogeographical distribution in insular environments are mostly explained by the geological age, littoral area (which is correlated to the island geological age: insular shelves are larger in older islands), the isolation and the latitude. Therefore, older islands systems would exhibit higher species richness compared to younger islands (Ávila et al. 2018). Additionally, species geographical expansion and distribution are shaped by the successive interglacial (species migration toward higher latitudes) and glacial (tropical species disappearance in higher latitude) episodes. In consequences, islands in higher latitudes would be greatly influenced while islands in lower latitude would present a higher diversity and endemism. In Macaronesia, this trend has been confirmed, the southern archipelagos, Canary and Cape Verde, exhibiting more speciose marine taxa (Freitas et al. 2019). Based on these criteria and previous studies, it would be expected that Canary and Cape Verde jellyfish diversity would follow the same trend. Yet, jellyfish were more speciose in Azores (50\%) compared with Canary (45\%) and Cape Verde (38\%). However, by looking closely, Cape Verde presents a higher number of meroplankton species as well as the highest endemism in hydrozoan in accordance with the observations preformed on different marine taxa (Table 3). From the present dataset, two biogeographical sister areas can be identified on hydrozoan life cycle strategy: Azores and Canary Islands with holoplanktonic-dominance, and Cape Verde with meroplanktonic-dominant community.

Among the different factors affecting marine plankton biogeography (Barton et al. 2013), the influence of oceanic currents in marine organism's dispersion and distance to the continent or nearest islands are considered to play an important role in an archipelago's biogeography (Whittaker and Fernández-Palacios 2007). The Azores Current, supplied by the Gulf Stream, flows eastward, feeding the eastern subtropical boundary area. One branch loops in the south, supplying the Canary Current by two branches separated by Madeira (Barton 2001). Therefore, considering this ocean circulation pattern, coupled with the relatively close distance between the three archipelagos, a larger number of common species was expected. However, except for few taxa (macroalgae and brachyurans), the number species occurring in all the archipelagos is low in most of studied marine taxa (Table 3). Recent physical oceanography study in the region, Sala et al. (2013) evaluated using a numerical model (Regional Oceanic Modeling System coupled with the Lagrangian off-line numerical tool, Ariane, and Argo buoy data) that, all depths combined (up to $2000 \mathrm{~m}$ ), only a few particles (up to 7\%) released in the Azores have reached the two other Lusitanian archipelagos (Madeira and the Canary Islands). This would explain the low degree of similarity among the AzoresMadeira-Canary Islands jellyfish species. Lusitania also displays substantial exchanges with the Strait of Gibraltar (Sala et al. 2013), facilitating species dispersion between the Eastern Atlantic and the Mediterranean Sea (45\% of common jellyfish species between Macaronesia and Mediterranean Sea). Traditionally, Cape Verde has been considered hydrologically separated from the complex Azores-Madeira-Canary Islands due to the Cape Verde Frontal Zone, this being considered an effective barrier separating the South Atlantic Central Water (SACW) (tropical region) from the North Atlantic Central Water (NACW) (subtropical region). However, this barrier breaks down over the African slope between Cape Verde and Cape Blanc: water exchanges between the SACW and the NACW have been outlined as Cape Verde SACW follows northwards along the African slope and crosses the CVFZ (mass flux estimated at $0.7 \mathrm{~Sv}$ ), reaching at least $24^{\circ} \mathrm{N}$ (Peña-Izquierdo et al. 2012; Pelegrí et al. 2017). The present similarity between the tropical and northern archipelagos, and between the four archipelagos in general, is mainly related to the wide distribution of the holoplanktonic species.

The majority of epipelagic jellyfish species recorded in Macaronesia display a wide distribution in temperate and subtropical-tropical regions, explained by the dominance of siphonophores, most of which exhibit a cosmopolitan distribution (Mapstone 2014). Nevertheless, based on the species with stricter affinities, two clades can be identified: (i) Azores-Madeira-Canary with temperate and subtropical and/or tropical affinity; (ii) Cape Verde with subtropical-tropical affinity. The pattern we describe here for jellyfish diversity in Macaronesia differs from the classification proposed by Freitas et al. (2019) and Spalding et al. (2007). 
However, richness estimators as well as unequal sampling effort within the Macaronesia archipelagos suggest that species richness has probably been significantly underestimated. This is especially noticeable for Madeira which has been poorly studied compared to the three other archipelagos of Macaronesia, as confirmed by the limited number of publications (Supplement 3). However, recent sampling campaigns have revealed a higher level of diversity, including over 10 new records for the area (Gueroun, personal communication).

The present study constitutes the first biodiversity survey on jellyfish diversity across the islands of Macaronesia. This pioneering step forward will act as a baseline study for future research on the biodiversity, temporal occurrence and spatial distribution patterns of jellyfish assemblages in Macaronesia as well as other global insular ecosystems.

Supplementary Information The online version contains supplementary material available at https://doi.org/10.1007/s12526-021-01174-z.

Acknowledgements This work was supported by the project GoJelly-A gelatinous solution to plastic pollution-funding from the European Union's Horizon 2020 research and innovation programme under grant agreement No. 774499. This study also had the support of Fundação para a Ciência e Tecnologia (FCT), through the strategic project [UIDB/04292/2020] granted to MARE UI\&I. JCC is funded by national funds through FCTFundação para a Ciência e a Tecnologia, I.P., under the Scientific Employment Stimulus-Institutional Call-[CEECINST/ 00098/2018]. We thank the Editor and two anonymous Referees for their constructive criticism and valuable observations that greatly strengthened the original manuscript.

Funding This work was funded by the project GoJelly-A gelatinous solution to plastic pollution-funding from the European Union's Horizon 2020 research and innovation programme (grant agreement No. 774499). This study also had the support of Fundação para a Ciência e Tecnologia (FCT), through the strategic project (UIDB/04292/2020) granted to MARE UI\&I. JCC is funded by national funds through FCT - Fundação para a Ciência e a Tecnologia, I.P., under the Scientific Employment Stimulus - Institutional Call - (CEECINST/ 00098/2018]).

\section{Declarations}

Conflict of interest The authors declare that they have no conflict of interest.

Ethical approval No animal testing was performed during this study.

Sampling and field studies The study does not contain sampling material or data from field studies.

Data availability The datasets generated during and/or analysed during the current study are available from the corresponding author on reasonable request.

Authors' contributions Conceptualization SKM and JCC; methodology SKMG and JCC; formal analyses and investigation SKMG; writing- original draft preparation SKMG, CA, JJ and JCC; writing-review and editing SKMG, CA, NN, MF, JJ and JCC; funding acquisition JCC, CA and JCC.

Open Access This article is licensed under a Creative Commons Attribution 4.0 International License, which permits use, sharing, adaptation, distribution and reproduction in any medium or format, as long as you give appropriate credit to the original author(s) and the source, provide a link to the Creative Commons licence, and indicate if changes were made. The images or other third party material in this article are included in the article's Creative Commons licence, unless indicated otherwise in a credit line to the material. If material is not included in the article's Creative Commons licence and your intended use is not permitted by statutory regulation or exceeds the permitted use, you will need to obtain permission directly from the copyright holder. To view a copy of this licence, visit http://creativecommons.org/licenses/by/4.0/.

\section{References}

Arai MN (1997) A functional biology of Scyphozoa. Chapman \& Hall, London

Ávila SP, Cordeiro R, Madeira P, Silva L, Medeiros A, Rebelo AC, Melo C, Neto AI, Haroun R, Monteiro A, Rijsdijk K, Johnson M (2018) Global change impacts on large-scale biogeographic patterns of marine organisms on Atlantic oceanic islands. Mar Pollut Bull 126: 101-112. https://doi.org/10.1016/j.marpolbul.2017.10.087

Barton ED (2001) Canary and Portugal Currents. In: Steele JH (ed) Encyclopedia of Ocean Sciences, 2sd edn, Academic. Press, London, pp 380-389

Barton AD, Pershing AJ, Litchman E, Record NR, Edwards KF, Finkel ZV, Kiørboe T, Ward BA (2013) The biogeography of marine plankton traits. Ecol Lett 16:522-534. https://doi.org/10.1111/ele. 12063

Baxter EJ, Rodger HD, McAllen R, Doyle TK (2011) Gill disorders in marine-farmed salmon: investigating the role of hydrozoan jellyfish. Aquac Environ Interact 1:245-257. https://doi.org/10.3354/ aei00024

Bigelow H (1938) Plankton of the Bermuda oceanographic expeditions. VIII. Medusae taken during the years 1929 and 1930. 23 Part2(5-9): VIII. Zool New York 23:99-189

Bosch-Belmar M, M'Rabet C, Dhaouadi R et al (2016) Jellyfish Stings Trigger Gill Disorders and Increased Mortality in Farmed Sparus aurata (Linnaeus, 1758) in the Mediterranean Sea. PLoS One 11: e0154239. https://doi.org/10.1371/journal.pone.0154239

Bouillon J, Medel MD, Pagès F, Gili JM, Boero F, Gravili C (2004) Fauna of the Mediterranean Hydrozoa. Sci Mar 68:5-438

Bouillon J, Gravili C, Pagès F, Gili JM, Boero F (2006) An introduction to Hydrozoa. Muséum national d'Histoire naturelle, Paris

Cairns SD, Gershwin L, Brook FJ, Pugh P, Dawson EW, Ocaña VO, Vervoort W, Williams G, Watson JE, Opresko DM, Schuchert P, Hine PM, Gordon DP, Campbell HJ, Wright AJ, Sãnchez JA (2009) Phylum Cnidaria: Corals, medusae, hydroids, myxozoans. In: Gordon D (ed) New Zealand Inventory of Biodiversity. Volume 1. Kingdom Animalia: Radiata, Lophotrochozoa, Deuterostomia. Canterbury University Press, Christchurch, pp 47-74

Canning-Clode J, Valdivia N, Molis M, Thomason JC, Whal M (2008) Estimation of regional richness in marine benthic communities : quantifying the error. Limnol Oceanogr Methods 6:580-590. https://doi.org/10.4319/lom.2008.6.580

Carracedo JC (2001) Volcanismo reciente y riesgo volcánico. In: Fernández-Palacios J, Martín J (eds) Naturaleza de las Islas Canarias: Ecología y conservación. Turquesa, Santa Cruz de Tenerife, Canary Islands, pp 65-76 
Chao A, Ma KH, Hsieh TC, Chiu C-H (2016) SpadeR (Species-richness prediction and diversity estimation in R): an R package in CRAN

Condon RH, Graham WM, Duarte CM, Pitt KA, Lucas CH, Haddock SHD, Sutherlan KR, Robinson KL, Dawson MN, Decker MD, Mills CE, Purcell JE, Malej A, Mianzan H, Uye SI, Gelcich S, Madin P (2012) Questioning the rise of gelatinous zooplankton in the world's oceans. Bioscience 62:160-169. https://doi.org/10.1525/bio.2012. 62.2 .9

Condon RH, Duarte CM, Pitt KA, Robinson KL, Lucas CH, Sutherlan KR, Mianza HW, Bogeber M, Purcell JE, Decker MB, Uye SI, Madin LP, Brodeur RD, Haddock SH, Malej A, Parry GD, Eriksen E, Quiñones J, Acha M, Harvey M, Arthur JM, Graham WM (2013) Recurrent jellyfish blooms are a consequence of global oscillations. Proc Natl Acad Sci U S A 110:1000-1005. https://doi. org/10.1073/pnas.1210920110

Daly M, Brulgler MR, Cartwright P, Collins AG, Dawson MN, Fautin DG, France SC, McFadden CS, Opresko DM, Rodriguez E, Romano SL, Stake JL (2007) The phylum Cnidaria: a review of phylogenetic patterns and diversity 300 years after Linnaeus. Zootaxa 1668:127182. https://doi.org/10.11646/zootaxa.1668.1.11

Dansereau P (1961) Etudes macaronésiennes: géographie des cryptogames vasculaires. Agron Lusit 23:151-181

Engler A (1879) Entwicklungsgeschichte der Pflanzenwelt,insbesondere der Florengebiete seit der Tertiärperiode Vol1: Period: The extratropical areas of the northern hemisphere. W. Engelmann, Leipzig

Freitas R, Romeiras M, Silva L, Cordeiro R, Madeira P, González JA, Wirtz P, Falcón JM, Brito A, Floeter SR, Afonso P, Proteiro F, Viera-Rodriguez MA, Neto AI, Haroun R, Farminhao JN, Rebelo AC, Baptista L, Melo CS, Martinez A, Nunez J, Berning B, Johnson ME, Avila SP (2019) Restructuring of the 'Macaronesia' biogeographic unit : a marine multi- taxon biogeographical approach. Sci Rep 9:15792. https://doi.org/10.1038/s41598-019-51786-6

Garcia JR, Durbin E (1993) Zooplanktivorous predation by large scyphomedusae Phyllorhiza punctata (Cnidaria: Scyphozoa) in Laguna Joyuda. J Exp Mar Biol Ecol 173:71-93. https://doi.org/ 10.1016/0022-0981(93)90208-6

Ghermandi A, Galil B, Gowdy J, Nunes PALD (2015) Jellyfish outbreak impacts on recreation in the Mediterranean Sea: welfare estimates from a socioeconomic pilot survey in Israel. Ecosyst Serv 11:140 147. https://doi.org/10.1016/j.ecoser.2014.12.004

Gibbons MJ, Buecher E, Thibault-Botha D, Helm RR (2010) Patterns in marine hydrozoan richness and biogeography around southern Africa: implications of life cycle strategy. J Biogeogr 37:606-616. https://doi.org/10.1111/j.1365-2699.2009.02237.x

Haeckel E (1880) Das System der Acraspeden. 2te Hälfte des Systems der Medusen. Acht Nachträge zur Vervollständigung des Systems. Denkschriften der Med Gesellschaft zu Jena 2:361-672 plates 21-40

Horton T, Kroh A, Ahyong S, Bailly N, Boyko CB, Brandão SN, Gofas S, Hooper JNA, Hernandez F, Holovachov O, Mees J, Molodtsova TN, Paulay G, Decock W, Dekeyzer S, Lanssens T, Vandepitte L, Vanhoorne B, Adlard R (2020) World Register of Marine Species. https://www.marinespecies.org

Jarms G, Morandini AC (2019) World atlas of jellyfish. Dölling und Galitz Verlag, Hamburg

Jarms G, Tiemann H, Båmstedt U (2002) Development and biology of Periphylla periphylla (Scyphozoa: Coronatae) in a Norwegian fjord. Mar Biol 141:647-657. https://doi.org/10.1007/s00227-002-0858-x

Kingsford MJ, Mooney CJ (2014) The ecology of Box jellyfish (Cubozoa). In: Pitt KA, Lucas CH (eds) Jellyfish Blooms. Springer Netherlands, Dordrech, pp 267-302. https://doi.org/10. 1007/978-94-007-7015-7 12

Kramp PL (1955) The medusae of the Tropical West Coast of Africa. Atlantide Report 3:239-324

Kramp PL (1961) Synopsis of the Medusae of the world. J Mar Biol Assoc UK 40:1-469
Lloris D, Rucabado J, Figueroa H (1991) Biogeography of the Macaronesian ichthyofauna (the Azores, Madeira, the Canary islands, Cape Verde and the African enclave). Bol Mus Munic do Funchal 43:191-241

Lucas CH, Dawson MN (2014) What are jellyfishes and thaliaceans and why do they bloom? In: Pitt KA, Lucas CH (eds) Jellyfish Blooms. Springer Netherlands, Dordrech, pp 9-44. https://doi.org/10.1007/ 978-94-007-7015-7_2

Mapstone GM (2014) Global diversity and review of Siphonophorae (Cnidaria : Hydrozoa). PLoS One 9:e87737. https://doi.org/10. 1371/journal.pone.0087737

Marques R, Bouvier C, Darnaude AM, Molinero JC, Przybyla C, Soriano S, Tomasini JA, Bonnet D (2016) Jellyfish as an alternative source of food for opportunistic fishes. J Exp Mar Biol Ecol 485:1-7. https://doi.org/10.1016/j.jembe.2016.08.008

Matsumoto GI, Raskoff KA, Lindsay DJ (2003) Tiburonia granrojo n . sp ., a mesopelagic scyphomedusae from the Pacific Ocean representing the type of a new subfamily ( class Scyphozoa : order Semaeostomeae : family Ulmaridae : subfamily Tiburoniinae subfam . nov .). Mar Biol 143:73-77. https://doi.org/10.1007/ s00227-003-1047-2

Morandini AC (2003) Deep-sea medusae (Cnidaria : Cubozoa, Hydrozoa and Scyphozoa) from the coast of Bahia (western South Atlantic , Brazil). Mitteilungen Aus Dem Hambg Zool Museum Und Inst 100: $13-25$

Morton B, Britton JC, Frias Martins AM (1998) Coastal ecology of the Açores. Sociedade Afonso Chaves, Ponta Delgada

Pelegrí JL, Peña-Izquierdo J, Machin F, Meiners C, Presas-Navarro C (2017) Oceanography of the Cape Verde Basin and Mauritanian Slope Waters. In: Ramos A, Ramil F, Sanz JL (eds) Deep-Sea Ecosystems Off Mauritania: Research of Marine Biodiversity and Habitats in the Northwest African Margin, 1st edn. Springer, Netherlands, pp 119-153

Peña-Izquierdo J, Pelegrí JL, Pastor MV, Castellanos P, Emelianov M, Gasser M, Salvador J, Vázquez-Domínguez E (2012) The continental slope current system between Cape Verde and the Canary Islands. Sci Mar 76:65-78. https://doi.org/10.3989/scimar.03607. $18 \mathrm{c}$

Purcell JE, Uye S, Lo W-T (2007) Anthropogenic causes of jellyfish blooms and their direct consequences for humans : a review. Mar Ecol Prog Ser 350:153-174. https://doi.org/10.3354/meps07093

Purcell JE, Milisenda G, Rizzo A, Carrion SA, Zampardi S, Airoldi S, Zagami G, Guglielmo L, Boero F, Doyle TK, Piraino S (2015) Digestion and predation rates of zooplankton by the pleustonic hydrozoan Velella velella and widespread blooms in 2013 and 2014. J Plankton Res 37:1056-1067. https://doi.org/10.1093/plankt/fbv031

Quinteiro J, Manent P, Pérez-Diéguez L, González JA, Almeida C, Lopes E, Araújo R, Carreira GP, Rey-Méndez M, González-Henríquez N (2015) Phylogeography of a marine insular endemic in the Atlantic Macaronesia: The Azorean barnacle, Megabalanus azoricus (Pilsbry, 1916). PLoS One 10. https://doi.org/10.1371/journal. pone. 0124707

R Core Team (2017). R: A language and environment for statistical computing. R Foundation for Statistical Computing, Vienna, Austria. URL http://www.R-project.org/

Ronowicz M, Peña Cantero ÁL, Mercado Casares B, Kukliński P, Soto Àngel JJ (2019) Assessing patterns of diversity, bathymetry and distribution at the poles using Hydrozoa (Cnidaria) as a model group. Hydrobiologia 833:25-51. https://doi.org/10.1007/s10750018-3876-5

Rottini Sandrini L, Avian M (1991) Reproduction of Pelagia noctiluca in the central and northern Adriatic Sea. Hydrobiologia 216(217):197202

Sabatés A, Pagès F, Atienza D, Fuentes VL, Purcell JE, Gili J-M (2010) Planktonic cnidarian distribution and feeding of Pelagia noctiluca in 
the NW Mediterranean Sea. Hydrobiologia 645:153-165. https:// doi.org/10.1007/s10750-010-0221-z

Sala I, Caldeira RM, Estrada-allis SN, Froufe E, Couvelard X (2013) Lagrangian transport pathways in the northeast Atlantic and their environmental impact. Limnol Oceanogr Fluids Environ 3:40-60. https://doi.org/10.1215/21573689-2152611

Sangil C, Martins GM, Hernández JC, Alves F, Neto AI, Ribeiro C, León-Cisneros K, Canning-Clode J, Rosas-Alquicira E, Mendoza JC, Titley I, Wallenstein F, Couto RP, Kaufmann M (2018) Shallow subtidal macroalgae in the North-eastern Atlantic archipelagos (Macaronesian region): a spatial approach to community structure. Eur J Phycol 53:83-98. https://doi.org/10.1080/09670262. 2017.1385098

Sanz-Martín M, Pitt KA, Condon RH, Lucas CH, Novaes de Santana C, Duarte CM (2016) Flawed citation practices facilitate the unsubstantiated perception of a global trend toward increased jellyfish blooms. Glob Ecol Biogeogr 25:1039-1049. https://doi.org/10.1111/geb. 12474

Schuchert P (1996) The marine fauna of New Zealand: athecate hydroids and their medusae (Cnidaria: Hydrozoa). New Zealand Oceonographic Insitute Memoir 106, Wellington

Smith EP, van Belle G (1984) Nonparametric estimation of species richness. Biometrics 40:119-129

Spalding MD, Fox HE, Allen GR, Davidson N, Ferdaña ZA, Finlayson MAX, Halpern BS, Jorge MA, Lombana AL, Lourie SA, Martin KD, Manus MC, Molnar J, Recchia CA, Robertson J (2007) Marine Ecoregions of the World : A Bioregionalization of Coastal and Shelf Areas. Bioscience 57:573-583. https://doi.org/10.1641/B570707

Sweetman AK, Chapman A (2015) First assessment of flux rates of jellyfish carcasses (jelly-falls) to the benthos reveals the importance of gelatinous material for biological C-cycling in jellyfishdominated ecosystems. Front Mar Sci 2:1-7. https://doi.org/10. 3389/fmars.2015.00047
Thiebot JB, Arnould JPY, Gómez-Laich A, Ito K, Kato A, Mattern T, Mitamura H, Noda T, Poupart T, Quintana F, Raclot T, RopertCoudert Y, Sala JE, Seddon PJ, Sutton GJ, Yoda K, Takahashi A (2017) Jellyfish and other gelata as food for four penguin species insights from predator-borne videos. Front Ecol Environ. https://doi. org/10.1002/fee. 1529

Tilves U, Fuentes V, Purcell JE, Torrents A, Pascual M, Raya V, Gili JM, Sabatés A (2016) Natural diet and predation impacts of Pelagia noctiluca on fish eggs and larvae in the NW Mediterranean. J Plankton Res 38:1243-1254. https://doi.org/10.1093/plankt/fbw059

Tuya F, Haroun RJ (2009) Phytogeography of Lusitanian Macaronesia: biogeographic affinities in species richness and assemblage composition. Eur J Phycol 44:405-413. https://doi.org/10.1080/ 09670260902836246

Vandendriessche S, Vansteenbrugge L, Derweduwen J, Maelfait H, Hostens K (2016) Jellyfish jelly press and jelly perception. J Coast Conserv 20:117-125. https://doi.org/10.1007/s11852-016-0423-2

Vanderpoorten A, Rumsey FJ, Carine MA (2007) Does Macaronesia exist? Conflicting signal in the bryophyte and pteridophyte floras. Am J Bot 94:625-639. https://doi.org/10.3732/ajb.94.4.625

Vervoort W, Watson JE (2003) The marine fauna of New Zealand: Leptothecata (Cnidaria: Hydrozoa) (Thecate Hydroids). NIWA (National Institute of Water and Atmospheric Research), Wellington

Wallis GP, Trewick SA (2009) New Zealand phylogeography : evolution on a small continent. Mol Ecol 18:3548-3580. https://doi.org/10. 1111/j.1365-294X.2009.04294.x

Whittaker RJ, Fernández-Palacios JM (2007) Island Biogeography: ecology, evolution, and conservation, 2nd edn. Oxford University Press, New York

Publisher's note Springer Nature remains neutral with regard to jurisdictional claims in published maps and institutional affiliations. 